\title{
LITERATURE REVIEW : KUALITAS SUMUR GALI DAN PERSONAL HYGIEN BERHUBUNGAN DENGAN GANGGUAN KESEHATAN KULIT DI INDONESIA
}

\author{
LITERATURE REVIEW : DUG WELL QUALITY AND PERSONAL HYGIENE WITH \\ SKIN HEALTH PROBLEMS IN INDONESIA
}

\author{
Farida Sugiester $\mathbf{S}^{1}$, Tri Joko ${ }^{2}$, Nurjazuli ${ }^{3}$ \\ 1,2,3 Magister Kesehatan Masyarakat, Universitas Diponegoro \\ Jl. Prof. Sudarto No.13, Tembalang, Kec. Tembalang. Semarang, Jawa Tengah. Indonesia \\ ${ }^{*}$ E-mail: faridasugiester19@gmail.com
}

\begin{abstract}
Indonesia has enormous water resource potential, reaching 3.9 trillion cubic meters per year. there are still around 3.2 trillion cubic meters per year or about 82.31 percent which has not been utilized. Skin disorders usually occur due to several factors, such as climate, environment, living habits, place of residence, allergies, and so on. This research is a literature review. Dug well is a source of water that comes from groundwater and is easily exposed to various pollutants that damage the quality of well water. The need for clean water from time to time increases rapidly, in line with the increasing population and increasing human activities in accordance with the demands of life which continues to grow to meet various needs. Personal hygiene determines one's health status consciously in maintaining health and preventing disease, especially skin disorders. The skin is one of the vital aspects that need to be considered in personal hygiene. Once the skin is vital, then every skin disorder can cause serious problems in health. Based on the results of research and discussion, it can be concluded that there is a significant relationship between the quality of dug wells and personal hygiene with complaints of skin disorders in people in various regions. Suggestions from this study are for the next literature writer, looking for varied literature sources so that the theme that will be used as literature is broader and deeper.
\end{abstract}

Key words: Dug Well; Personal Hygiene; Skin Disorders

\begin{abstract}
ABSTRAK
Indonesia mempunyai potensi sumber daya air yang sangat besar, yakni mencapai 3,9 trilyun meter kubik per tahun. masih terdapat sekitar 3,2 triliun meter kubik per tahun atau sekitar 82,31 persen yang belum dimanfaatkan. Gangguan kulit biasanya terjadi karena adanya beberapa faktor yang menjadi penyebab, misalnya iklim, lingkungan, kebiasaan hidup, tempat tinggal, alergi, dan lain sebagainya. Menurut Ayu (2019) Berdasarkan pemeriksaan Chi-Square yang digunakan untuk mengetahui faktor-faktor yang berhubungan dengan kejadian penyakit kulit, kebersihan pribadi $(p=0,038)$, riwayat pekerjaan $(p=0,705)$, periode perumahan $(p=1,00)$, rumah jarak dari Panau Power Plant $(p=0,053)$ dan riwayat alergi $(\mathrm{p}=0,048)$. Kebersihan pribadi dan riwayat alergi sebagai faktor yang berhubungan dengan kejadian penyakit kulit terhadap orang yang tinggal di dekat pembangkit listrik tenaga uap Panau, Palu, Indonesia.Penelitian ini merupakan literatur review.Sumur gali merupakan salah satu sumber air yang berasal dari air tanah dan mudah sekali terpapar oleh berbagai pencemar yang merusak kualitas air sumur.. Personal hygiene seseorang menentukan status kesehatan secara sadar dalam menjaga kesehatan dan mencegah terjadinya penyakit terutama gangguan pada kulit. Kulit adalah salah satu aspek vital yang perlu diperhatikan dalam higiene persorangan.Berdasarkan hasil penelitian dan pembahasan dapat diperoleh kesimpulan terdapat hubungan yang bermakna antara kualitas sumur air gali dan personal hygiene dengan keluhan gangguan kulit pada masyarakat di berbagai daerah. Saran dari penelitian ini adalah untuk penulis literatur selanjutnya, mencari sumber literatur yang bervariasi agar tema yang akan dijadikan literatur lebih luas dan mendalam. Kata kunci: Sumur Gali; Personal Hygiene; Gangguan Kulit
\end{abstract}




\section{PENDAHULUAN}

Indonesia mempunyai potensi sumber daya air yang sangat besar, yakni mencapai 3,9 trilyun meter kubik per tahun. Potensi ini bisa dimanfaatkan untuk menunjang sektor pertanian, air baku bagi masyarakat perkotaan dan industri, pembangkit listrik, hingga pariwisata. Namun sayangnya, pengelolaan pemanfaatan potensi sumber daya air tersebut masih sangat rendah. Dari total 3,9 trilyun meter kubik per tahun hanya sekitar 17,69 persen atau sekitar 691,3 juta meter kubik per tahun yang dapat dimanfaatkan. Artinya masih terdapat sekitar 3,2 triliun meter kubik per tahun atau sekitar 82,31 persen yang belum dimanfaatkan(1). Peningkatan jumlah penduduk selalu diikuti dengan peningkatan kebutuhan lahan dan air. Hal ini menyebabkan intervensi manusia terhadap sumberdaya air semakin besar, yang menyebabkan terjadinya perubahan wilayah resapan air dan penurunan mutu air secara nyata.

Faktor lain yang juga perlu diperhitungkan adalah terjadinya perubahan iklim global yang akan berdampak luas pada sistem sumberdaya air yang ada. Salah satu dampak yang saat ini dirasakan adalah bencana banjir dan kekeringan yang semakin sering terjadi. Terdapat dua permasalahan yang diduga sebagai penyebab utama terjadinya kondisi di atas. Pertama, potensi ketersediaan air di Indonesia tidak terdistribusi secara merata antar wilayah. Permasalahan kedua adalah kurangnya wilayah penampungan air yang mempunyai kapasitas memadai(2). Air dan kesehatan merupakan dua hal yang saling berkaitan . Kualitas air yang dikonsumsi masyarakat dapat menentukan derajat kesehatan masyarakat tersebut (3). Hasil dari Riset Kesehatan Dasar Tahun 2016 di Indonesia penggunaan air bersih masyarakat bersumber dari PAM $(41,96 \%)$, air sumur bor/pompa $(15,42 \%)$, sumur gali terlindung $(21 \%)$, sumur gali tak terlindung $(6,04 \%)$, air permukaan $(1,5 \%)$ dan air hujan $(2,4 \%)(4)$. Sumur terlindung adalah air yang berasal dari dalam tanah yang digali dan lingkar sumur tersebut dilindungi oleh tembok paling sedikit 0,8 meter di atas tanah dan 3 meter ke bawah tanah, serta ada lantai semen sejauh 1 meter dari lingkar sumur; Mata air terlindung adalah sumber air permukaan tanah di mana air timbul dengan sendirinya dan terlindung dari air bekas pakai, bekas mandi, mencuci, atau lainnya.

Sumur tak terlindung adalah air yang berasal dari dalam tanah yang digali dan lingkar sumur tersebut tidak dilindungi oleh tembok dan lantai semen sejauh 1 meter dari lingkar sumur. Cara pengambilan air sumur terlindung maupun tak terlindung dengan menggunakan gayung atau ember, baik dengan maupun tanpa katrol; Mata air tak terlindung adalah sumber air permukaan tanah di mana air timbul dengan sendirinya tetapi tidak terlindung dari air bekas pakai, bekas mandi, mencuci, atau lainnya(5). Beberapa faktor yang memiliki keterkaitan dengan kualitas sumur gali yaitu rembesan yang berasal dari tempat pembuangan kotoran manusia, kakus/jamban dan hewan, dari limbah sumur karena lantai dan saluran air limbah yang tidak kedap air, keadaan konstruksi sumur yang tidak memperhatikan jarak antara sumur dengan sumber pencemar(6) Limbah rumah tangga memiliki dampak yang buruk bagi lingkungan. Banyak orang tidak menyadari besarnya pengaruh limbah rumah tangga terhadap kehidupan masyarakat dan kelestarian lingkungan. Menyalurkan limbah rumah tangga ke alam bebas tanpa melalui proses pengolahan, akan membawa dampak buruk yang berkepanjangan bagi keberlangsungan hidup ekosistem (7).

Gangguan kulit biasanya terjadi karena adanya beberapa faktor yang menjadi penyebab, misalnya iklim, lingkungan, kebiasaan hidup, tempat tinggal, alergi, dan lain sebagainya (8). Hasil penelitian yang dilakukan oleh Ayu (2019) Berdasarkan pemeriksaan Chi-Square yang digunakan untuk mengetahui faktor-faktor yang berhubungan dengan kejadian penyakit kulit, ditemukan bahwa kebersihan pribadi $(\mathrm{p}=0,038)$, riwayat pekerjaan $(p=0,705)$, periode perumahan $(p=1,00)$, rumah jarak dari Panau Power Plant $(p=0,053)$ dan riwayat alergi $(p=0,048)$. Kebersihan pribadi dan riwayat alergi sebagai faktor yang berhubungan dengan kejadian penyakit kulit terhadap orang yang tinggal di dekat pembangkit listrik tenaga uap Panau, Palu, Indonesia $(9)$

Menurut WHO (2013) indonesia hingga saat ini merupakan salah satu negara dengan beban penyakit kulit yang tinggi. Pada tahun 2013, Indonesia menempati urutan ketiga di dunia setelah India dan Brazil. Tahun 2013, Indonesia memiliki jumlah kasus penyakit kulit baru dengan jumlah 16.856 kasus dan jumlah kecacatan tingkat 2 di antara penderita baru sebanyak 9,86\% (10). Penyakit kulit semakin banyak berkembang, hal ini dibuktikan dari profil kesehatan Indonesia tahun 2016 yang menunjukkan bahwa penyakit kulit dan jaringan subkutan menjadi peringkat ketiga dari 10 penyakit terbanyak pada pasien rawat jalan di rumah sakit seIndonesia berdasarkan jumlah kunjungan yaitu sebanyak 192.414 kunjungan, kunjungan kasus baru

122.076 kunjungan sedangkan kasus lama 70.338 kunjungan (11). Pemeliharaan personal hygiene 
berarti tindakan memelihara kebersihan dan kesehatan diri sesorang untuk kesejahteraan fisik dan psikisnya. Banyak manfaat yang dapat didapat dengan merawat personal hygiene, memperbaiki personal hygiene, mencegah penyakit, meningkatkan kepercayaan diri dan menciptakan keindahan. Personal hygiene seseorang menentukan status kesehatan secara sadar dalam menjaga kesehatan dan mencegah terjadinya penyakit terutama gangguan pada kulit. Cara menjaga kesehatan tersebut meliputi menjaga kebersihan kulit, kebiasaan mencuci tangan dan kuku, frekuensi mengganti pakaian, pemakaian handuk yang bersamaan, dan frekuensi mengganti sprei tempat tidur (12).

Pada penelitian yang dilakukan oleh Greita M.S.Timpal, dkk (2020) Hubungan Antara Personal Hygiene Dengan Keluhan Gangguan Kulit Di Asrama Putra Sma Kristen 2 (Binsus) Tomohon. Berdasarkan hasil penelitan di asrama putra SMA Kristen 2 (Binsus) Tomohon maka didapatkan hasil yaitu nilai $p=0,000$ dengan nilai kemaknaan $a=0,05$. Kesimpulannya yaitu terdapat hubungan antara personal hygiene dengan keluhan gangguan kulit di Asrama Siswa Putra SMA Kristen 2 (Binsus) Tomohon Hal ini disebabkan karena kurangnya kesadaran tentang personal hygiene dimana yang paling sering terjadi, siswa putra masih sering bertukar pakaian olahraga padahal sudah berkeringat karena digunakan sebelumnya . Selain itu handuk yang hanya diletakkan begitu saja tanpa dijemur dibawah sinar matahari, cara mencuci tangan yang masih salah, tidak mengikuti cara cuci tangan yang baik dan benar, kuku yang sengaja dipanjangkan dan kebiaasan tidur dikatil teman dan tidak membersihkan sprei sebelum tidur merupakan kebiasaan yang mempengaruhi terjadinya gangguan kulit (13). Tujuan menggunakan pendekatan literatur review ini untuk mengetahui Kualitas Sumur Gali Dan Personal hygiene Dengan Gangguan Kesehatan Kulit Di Indonesia berdasarkan hasil penelitian terdahulu yang di rangkum dalam penelitian berbasis kesehatan lingkungan.

\section{BAHAN DAN METODE}

Penelitian ini merupakan literatur review. Pengertian Systematic Literature Review merupakan istilah yang digunakan untuk merujuk pada metodologi penelitian atau riset tertentu dan pengembangan yang dilakukan untuk mengumpulkan serta mengevaluasi penelitian yang terkait pada fokus topik tertentu(14) Data base yang digunakan dalam pencarian artikel ini adalah Google Scholar, dengan menggunakan kata kunci " Sumur Gali , Personal hygiene Dan Gangguan Kulit ".yang telah dilakukan oleh peneliti sebelumnya di indonesia yang dapat dipertanggung jawabkan secara ilmiah. Tulisan yang dicari dan digunakan dalam penulisan ini adalah tulisan yang diterbitkan mulai dari tahun 2011 sampai tahun 2021 dari berbagai sumber jurnal baik nasional maupun internasional. Diperoleh 8 artikel dan dianalisis melalui analisis tujuan, kesesuaian topik, variabel yang digunakan, dan hasil dari setiap jurnal.

\section{HASIL DAN PEMBAHASAN}

Tabel 1. Variabel Dan Hasil Penelitian

\begin{tabular}{|c|c|c|c|c|}
\hline Penulis & Tujuan & Desain & Variabel & Hasil \\
\hline $\begin{array}{l}\text { Hera } \\
\text { Rachmawati } \\
\text { " Mursid } \\
\text { Raharjo, } \\
\text { Hanan } \\
\text { Lanang } \\
\text { (2019) }\end{array}$ & $\begin{array}{lr}\text { Untuk mengetahui } \\
\text { hubungan } & \text { kondisi } \\
\text { fisik sumur dan } \\
\text { penurunan kualitas } \\
\text { air (BOD) dengan } \\
\text { kejadian gangguan } \\
\text { kesehatan } \\
\text { dialami warga } \\
\text { Manjung. }\end{array}$ & $\begin{array}{l}\text { Observasional } \\
\text { analitik dengan } \\
\text { pendekatan case } \\
\text { control }\end{array}$ & $\begin{array}{l}\text { Kondisi } \\
\text { dinding sumur, } \\
\text { Kondisi bibir } \\
\text { sumur, Kondisi } \\
\text { lantai sumur, } \\
\text { Kadar BOD }\end{array}$ & $\begin{array}{l}\text { Hasil uji laboratorium kadar } \\
\text { BOD terdapat } 5 \text { sampel air } \\
\text { sumur atau sebesar 13,15\% } \\
\text { yang memiliki baku } \\
\text { mutu air badan air kelas I } \\
\text { dari } 38 \text { sampel air sumur. } \\
\text { Hasil uji hubungan } \\
\text { menunjukkan bahwa kondisi } \\
\text { dinding sumur ( } \\
\text { p-value= } 0,032 \text {; OR } \\
7,650(1,370 \quad 42,713)) \text {, kondisi } \\
\text { lantai sumur }(p \\
\text {-value= } 0,040 ; \text { OR }=5,926(1,287 \\
7,283)) \text {, } \\
\text { dan kadar BOD dalam sampel } \\
\text { air sumur (p-value }\end{array}$ \\
\hline
\end{tabular}


$=0,046)$ berhubungan dengan kejadian penyakit Kondisi bibir sumur $(\mathrm{p}$-value $=0,065 ; \mathrm{OR}=$ 6,182(1,10134,700)) tidak berhubungan dengan kejadian penyakit

Agsa Sajida Untuk menganalisis , Devi hubungan personal Nuraini hygiene (kebersihan Santi , Evi kulit, tangan dan Naria (2012) kuku, pakaian, handuk, sprei dan sanitasi lingkungan dengan remonstrance penyakit kulit di Kecamatan Denai Kecamatan Medan Denai Kota Medan

Andi Rizky Untuk mengetahui Amaliah, kualitas air sumur Ardianti (2020) gali ditinjau dari parameter kimia $(\mathrm{Cl}$ dan $\mathrm{Fe})$

Kelurahan Mangempang Kecamatan Barru Kabupaten Barru

$\begin{array}{llr}\text { Presilia } & \text { Untuk menganalisis } \\ \text { Jesika, Nur } & \text { hubungan } & \text { jenis } \\ \text { Hilal, } & \text { sumber air dan } \\ \text { Khomsatun } & \text { personal hygiene } \\ \text { (2016) } & \text { dengan } & \text { kejadian } \\ & \text { Dermatitis } & \end{array}$

Eliza Fitria, Untuk mengetahui Linda hubungan jenis Hayani(2021 ) sumber air dan personal hygiene dengan kejadian penyakit Dermatitis di Dusun Darul
Survey analitik Kebersihan dengan kulit, tangan rancangan cross sectional

Penelitian survey dengan deskriptif.

di

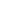

pakaian,

handuk, sprei

dan sanitasi

lingkungan,

keluhan

penyakit kulit pendekatan

kulit, tangan
dan

Hasil pengujian menunjukkan bahwa ada hubungan yang bermakna antara kebersihan kulit $(p=0,009)$, tangan dan kuku $(\mathrm{p}=0,001)$, pakaian $(\mathrm{p}=$ $0,011)$, handuk $(p=0,001)$, sprei dan sprei $(\mathrm{p}=0,025)$. Penyehatan lingkungan $(\mathrm{p}=$ $0,014)$ dengan keluhan penyakit kulit.

Klorida (Cl), Kualitas sumur gali parameter Besi (Fe), kimia $\mathrm{Cl}$ di Kelurahan Kualitas air Mangempang Kecamatan sumur gali Barru Kabupaten Barru dari 12 sumur gali yang diteliti ternyata 4

sumur gali tidak memenuhi syarat kesehatan yaitu $\leq 600$ $\mathrm{mg} / \mathrm{l}$. sedangkan kualitas sumur gali parameter kimia $\mathrm{Fe}$ di Kelurahan Ma ngempang Kecamatan Barru Kabupaten Barru dari 12 sumur gali yang diteliti ternyata 2 sumur

gali tidak memenuhi syarat kesehatan yaitu $\leq 1,0 \mathrm{mg} / 1$.

Observasional dan case control

Jenis kelamin, Hasil penelitian menunjukkan usia, sarana variabel yang memiliki sumber air dan hubungan dengan kejadian personal hygiene penyakit Dermatitis adalah yang terdiri jenis sumber air dengan nilai $p$ dari perilaku value $=0,001$, personal hygiene mandi, merupakan variabel yang tidak perilaku mimiliki hubungan dengan berpakaian dan kejadian penyakit Dermatitis di perilaku tidur Desa Kedungrandu dengan hasil nilai $\mathrm{p}$ value $=1,000$

Sumber air, Hasil penelitian menunjukkan personal hygiene, terdapat hubungan antara jenis dermatitis sumber air dengan kejadian penyakit Dermatitis $\mathrm{p}$ value $=$ 0,000 , yang berarti $p$ value $<a$ dan tidak ada hubungan antara personal hygiene dengan 


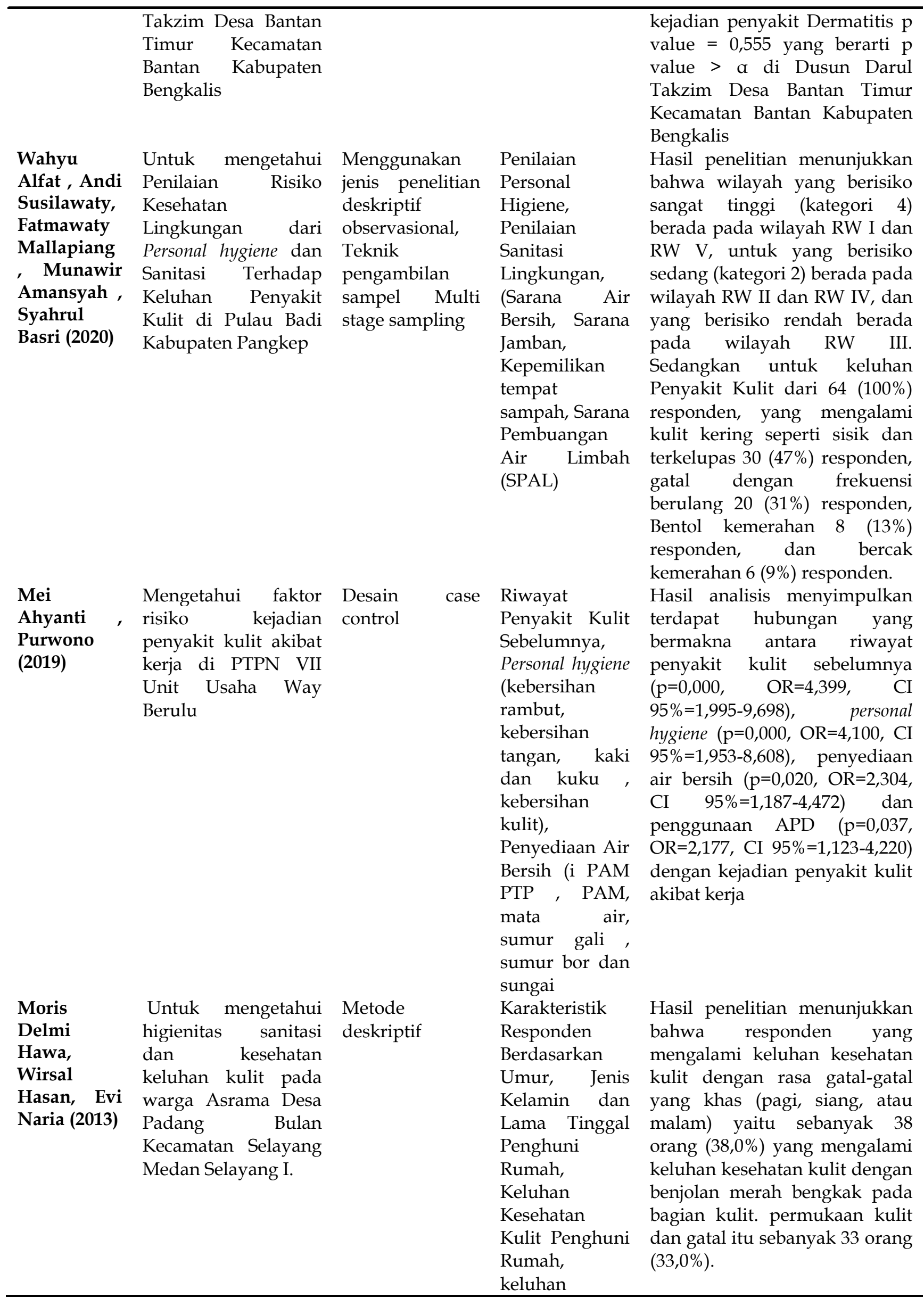




\begin{tabular}{ll}
\hline & kesehatan kulit \\
berdasarkan & karakteristik i \\
responden, & Keluhan \\
Kesehatan & Kulit \\
Responden & Berdasarkan \\
Personal & hygiene, \\
Komponen \\
Rumah Kost
\end{tabular}

\section{PEMBAHASAN}

\section{Kualitas Sumur Gali}

Sumur merupakan sumber utama tempat persediaan air bersih bagi masyarakat yang tinggal di daerah pedesaan maupun perkotaan di Indonesia. Biasanya sumur yang ada di Indonesia adalah sumur gali. Sumur gali merupakan salah satu sumber air yang berasal dari air tanah dan mudah sekali terpapar oleh berbagai pencemar yang merusak kualitas air sumur. Tingginya kejadian penyakit berbasis lingkungan disebabkan oleh masih buruknya kondisi sanitasi dasar terutama air bersih, rendahnya perilaku hidup bersih dan sehat (PHBS) masyarakat. Kondisi lingkungan yang buruk dapat menimbulkan penyakit-penyakat anataranya yaitu penyakit infeksi yaitu penyakit diare, kolera, typhoid fever, dan paratyphoid fever, disentri, dan penyakit kulit. (15). Pada kegiatan pemukiman dan perindustrian. Terdapat hubungan pada penggunaan lahan misalnya untuk aktivitas perkotaan dan industri dengan jumlah ketersediaan air bersih. Kegiatan yang dilakukan terhadap penggunaan lahan yang menyebabkan pencemaran air akibat kegiatan-kegiatan tersebut masih rendah. Kebutuhan air bersih dari waktu ke waktu meningkat dengan pesat, sejalan dengan bertambahnya jumlah penduduk dan meningkatnya aktivitas manusia sesuai dengan tuntutan kehidupan yang terus berkembang untuk mencukupi berbagai keperluan (16).

Tipe sumur gali ada 2 tipe tergantung pada kondisi tanah yang mudah atau tidaknya retak. Pada tipe I Bila keadaan tanah tidak menunjukan gejala mudah retak atau runtuh konstruksinya antara lain : Dinding atas dibuat dari pasangan bata/batako/batu belah yang diplester bagian luar dan dalam setinggi $80 \mathrm{~cm}$ dari permukaan lantai, dinding bawah dari bahan yang sama sedalam minimal $300 \mathrm{~cm}$ dari permukaan lantai. Sedangkan pada tipe II bila keadaan tanah menunjukkan gejala mudah retak atau runtuh. Konstruksinya : Dinding atas dibuat dari pasangan bata/batako/batu belah yang diplester bagian luar dan dalam setinggi $80 \mathrm{~cm}$ dari permukaan lantai, dinding bawah sampai kedalaman sumur dari pipa beton. sedalam minimal $300 \mathrm{~cm}$ dari permukaan lantai pipa beton harus kedap air, dan sisanya berlubang (17). Asal sumber pencemaran yang berbeda maka pencemaran yang dihasilkan akan berbeda pula. Pada kasus Industri Soun di Desa Manjung Kecamatan Ngawen Kabupaten Klaten, Dalam proses produksi, air digunakan dalam berbagai macam kegiatan seperti pencucian bahan baku, pendinginan, media untuk proses pengolahan, penguapan bahan olahan, maupun penunjang kegiatan sanitasi di dalam rumah produksi.akibatnya sumur gali yang terletak pada desa terkontaminasi limbah BOD. kadar BOD dalam sampel air sumur memiliki hubungan yang bermakna dengan kejadian gangguan pencernaan dan iritasi kulit yang terjadi, serta memiliki tingkat risiko hampir 15 kali lebih besar terserang penyakit gangguan pencernaan dan iritasi kulit daripada responden yang memiliki sumur gali dengan kadar BOD dalam air sumur yang memenuhi syarat. (18).

Sumber klorida dalam air permukaan dan air tanah dapat terjadi secara alami dan akibat aktivitas

manusia seperti air limpasan, penggunaan pupuk anorganik, air lindi dari persampahan, limbah septic tank, pakan ternak, limbah industri, saluran drainase atau irigasi, dan intrusi air laut di wilayah pesisir. Ion khlorida dalam air akan meningkat apabila kandungan mineral meningkat, karena disebabkan oleh jenis batuan. Selain itu, ion kholrida juga dapat bersumber dari urine manusai yaitu sekitar enam gram/hari/orang. Kandungan besi dalam air juga diperlukan, tetapi kandungan besi yang terlalu tinggi dapat menganggu kesehatan. Besi di dalam air dapat menimbulkan bau, rasa, warna kuning, pengendapan pada dinding pipa, kekeruhan, merusak dinding usus, dan dapat menyebabkan kematian. Kandungan zat besi yang melebihi $1 \mathrm{mg} / 1$ akan menyebabkan terjadinya iritasi pada mata dan kulit (19). 
Pencemaran air sumur gali tidak hanya berasal dari keberadaan dan jumlah sumber pencemar tetapi juga dipengaruhi oleh kondisi fisik sumur gali itu sendiri, yang meliputi tinggi bibir sumur, dinding sumur, lantai sumur, saluran buangan, dan jarak sumur dengan sumber pencemar serta praktik penggunaan dan pemeliharaan sumur gali. Menurut Presilia Jesika, dkk (2016) sumur gali dan mata air berisiko lebih besar terkena penyakit kulit salah satunya Dermatitis. Apabila sumur gali yang tidak ditutup dapat tercemar secara fisik seperti tercemar oleh daun, ranting dan kotoran lain. Sedangkan dinding sumur yang retak dapat menyebabkan pencemaran mikrobiologi dan kimia yang dikarena oleh letak sumur dekat dengan sumber pencemar biologi seperti kandang dan jamban dan sumber pencemar kimia seperti limbah hasil mencucian pakaian dan piring. Jumlah keseluruhan responden yang menggunakan sumur gali dari kelompok kasus maupun kelompok kontrol sejumlah $42(77,8 \%)(20)$.

\section{Personal Hygiene}

Faktor risiko penyakit kulit diantaranya perilaku hidup bersih dan sehat, kondisi sanitasi lingkungan, ketersediaan sumber air bersih, kebersihan badan, kuku, kulit, pakaian dan kondisi tempat tidur. Penularan penyakit kulit dapat melalui komponen lingkungan yang berisi agen penyakit serta senantiasa berinteraksi dengan manusia adalah air, udara, pangan, binatang dan serangga penular penyakit serta manusia itu sendiri. Kepadatan penghuni juga dapat mempengaruhi proses penularan atau perpindahan penyakit dari satu orang ke orang lain (21). Berdasarkan hasil survei yang dilakukan di masyarakat dan fasilitas kesehatan serta sumber data lainnya oleh Kementerian Kesehatan RI

didapatkan bahwa masyarakat yang berperilaku hidup bersih dan sehat di Indonesia mencapai angka $52,89 \%$ dimana Sulawesi Selatan khususnya menempati urutan ke 26 dengan presentase $46,60 \%$ masyarakatnya telah menggalakkan perilaku hidup bersih dan sehat (22). Pengetahuan tentang hygiene akan mempengaruhi praktik personal hygiene. Namun, hal ini saja tidak cukup, karena motivasi merupakan kunci penting dalam pelaksanaan hygiene tersebut. Permasalahan yang sering terjadi adalah ketiadaan motivasi karena kurangnya pengetahuan (23).

Manusia perlu menjaga kebersihan lingkungan dan kebersihan diri agar sehat, tidak bau, tidak malu, tidak menyebar kotoran, atau menularkan kuman penyakit bagi diri sendiri maupun orang lain, kersihan badan meliputi kebersihan diri sendiri, seperti mandi, menyikat gigi, mencuci tangan, dan memaka pakaian yang bersih(24) Pemeliharaan personal hygiene sangat menentukan status kesehatan, dimana individu secara sadar dan atas inisiatif diri sendiri untuk menjaga kesehatan dan mencegah terjadinya penyakit (25). Kulit adalah bagian terluar dari tubuh yang memiliki fungsi sebagai pelindung tubuh dari segala kerusakan atau pengaruh lingkungan yang buruk. Adapun fungsi kulit lainnya, yaitu : kulit sebagai tempat penyimpanan, kulit sebagai pengatur suhu, kulit sebagai alat peraba, kulit sebagai penunjang penampilan, dan masih banyak lagi (26) Setiap kali sel-sel ini mendeteksi zat yang mencurigakan, mereka memulai reaksi berantai pada kulit yang menyebabkan peradangan apabila kontak.

Pada penelitian yang dilakukan oleh Agsa Sajida, dkk (2012) tentang Hubungan Personal hygiene Dan Sanitasi Lingkungan Dengan Keluhan Penyakit Kulit Di Kelurahan Denai Kecamatan Medan Denai Kota Medan. Ada hubungan yang bermakna antara kebersihan kulit $(p=0,009)$, kebersihan tangan dan kuku $(p=0,001)$, kebersihan pakaian $(p=0,011)$, kebersihan handuk $(\mathrm{p}=0,001)$, kebersihan tempat tidur dan sprei $(p=0,025)$ dan sanitasi lingkungan $(p=0,014)$ dengan keluhan penyakit kulit (27). Penelitian serupa yang diteliti oleh Wahyu Alfat(2020) tentang Penilaian Risiko Kesehatan Lingkungan Dari Personal hygiene Dan Sanitasi Terhadap Keluhan Penyakit Kulit Di Pulau Badi Kabupaten Pangkep. Berdasarkan hasil analisis terkait dengan personal hygiene, persentase tertinggi pada variabel kebersihan tempat tidur dan sprei sebanyak $87,5 \%$ dengan wilayah yang tertinggi pada RW I sebanyak 25\% (28).

\section{Gangguan Kulit}

Kulit adalah salah satu aspek vital yang perlu diperhatikan dalam higiene persorangan. Begitu vitalnya kulit, maka setiap ada gangguan kulit, dapat menimbulkan berbagai masalah yang serius dalam kesehatan. Sebagai organ yang berfungsi sebagai proteksi, kulit memegang peranan penting dalam meminimalkan setiap gangguan dan ancaman yang akan masuk melewati kulit (23). Penyakit-penyakit yang diderita oleh suatu komunitas biasanya tidak spesifik, multiple agents dan multiple simptomps (gejala) sehingga sulit untuk menentukan mana sebab dan akibat. Dengan melakukan analisis hubungan, sering kali menunjukkan tingkat hubungan yang tinggi antara berbagai gejala dengan parameter lingkungan atau sanitasi dasar yang buruk (21). Menurut Lili Legiawat, dkk (2017) dari hasil data yang didapatkan ada lima penyakit terbanyak hampir sama dari tahun ke tahun (2008 - 2013), yaitu dermatitis, tumor kulit, 
kelainan kosmetik, penyakit infeksi, dan xerosis cutis. (29).

Saat kulit meradang atau iritasi setelah menyentuh atau kontak langsung dengan bendabenda atau zat-zat tertentu, inilah yang dinamakan dermatitis kontak. Gejalanya antara lain ditandai dengan ruam kemerahan, rasa gatal, kulit meradang, pecah-pecah, bahkan bengkak disertai rasa nyeri. Dermatitis kontak terjadi bila kulit bersentuhan langsung dengan zat tertentu yang menyebabkan iritasi atau memicu reaksi alergi.(30). Menurut Mei Ahyanti dkk, (2019) Bentuk kelainan yang paling banyak diderita pada para pekerja adalah gatal, kemerahan dan kulit kering serta kulit bersisik, sedangkan bagian tubuh yang paling banyak menderita sakit adalah telapak tangan, lengan tangan, kaki, leher, punggung dan sela-sela jari yang merupakan tanda penyakit dermatitis kontak pada pekerja. Pekerja yang pernah menderita penyakit kulit sebelumnya mempunyai risiko 4,399 kali untuk menderita penyakit kulit akibat kerja dibandingkan dengan pekerja yang sebelumnya tidak pernah menderita penyakit kulit. Ini dilihat dari hasil Distribusi Responden Berdasarkan Faktor Risiko dengan Kejadian Penyakit Kulit. Pada kelompok pekerja yang bukan penderita penyakit kulit dan pernah menderita penyakit kulit sebelumnya sebanyak $15,1 \%$ dan dan tidak pernah menderita penyakit kulit sebelumnya sebanyak $84,9 \%$. Hasil uji statistik mendapatkan nilai $\mathrm{p}=0,000<\mathrm{a}(0,050), \mathrm{OR}=4,399$ (CI 95\%=1,995-9,698). Penyakit kulit bisa disebabkan oleh beberapa faktor,

diantaranya faktor lingkungan dan kebiasaan seharihari dari pekerja.

Kejadian penyakit kulit yang saat ini dialami dapat disebabkan karena sebelumnya pekerja pernah mengalami penyakit kulit dan terjadi kekambuhan karena adanya pencetus. Salah satu pencetusnya adalah paparan zat-zat kimia yang ditambahkan saat proses pengolahan karet yaitu amoniak dan asam semut. Reaksi berlebihan terhadap bahan tertentu akan menjadi pemicu timbulnya kembali penyakit kulit yang diderita sebelumnya yang di sebut dengan alergi(31) penelitian serupa pada Moris Delmi Hawa, dkk (2013) Berdasarkan karakteristik responden sebagian besar responden yang mengalami keluhan kesehatan kulit adalah laki-laki yaitu 37 orang $(37,0 \%)$. penghuni rumah kost laki-laki cenderung kurang memperhatikan personal hygiene dibandingkan dengan penghuni rumah kost perempuan. responden yang mengalami keluhan kesehatan kulit rasa gatal-gatal yang khas (pagi, siang, ataupun malam) yaitu 38 orang $(38,0 \%)$ dan keluhan kesehatan kulit bentol-bentol merah pada permukaan kulit dan terasa gatal yaitu 33 orang $(33,0 \%)$. Sedangkan responden yang mengalami keluhan kesehatan kulit berupa rasa gatal-gatal yang khas (pagi, siang, ataupun malam) dan adanya bentol-bentol merah pada permukaan kulit dan terasa gatal yaitu sebanyak 22 orang $(22,0 \%)$.

\section{KESIMPULAN DAN SARAN}

Berdasarkan hasil penelitian dan pembahasan dapat diperoleh kesimpulan terdapat hubungan yang bermakna antara kualitas sumur air gali dan personal hygiene dengan keluhan gangguan kulit pada masyarakat di berbagai daerah . Kulit juga sangat kompleks, elastis dan sensitif, bervariasi pada keadaan iklim, umur, seks, ras dan juga bergantung pada lokasi tubuh. Lingkungan yang kotor akan menjadi sumber munculnya berbagai macam penyakit kulit. Saran dari penelitian ini adalah untuk penulis literatur selanjutnya, mencari sumber literatur yang bervariasi agar tema yang akan dijadikan literatur lebih luas dan mendalam.

\section{UCAPAN TERIMAKASIH}

Ucapan terima kasih disampaikan kepada Program Studi Magister Kesehatan Lingkungan Universitas Diponegoro Semarang. Dan kedua dosen pembimbing saya .

\section{DAFTAR PUSTAKA}

1. Direktorat Jenderal Sumber Daya Air KP. Rencana Strategis Direktorat Jenderal Sumber Daya Air. 2019;1-178.

2. Badan Pusat Statistik Indonesia. Statistik Lingkungan Hidup Indonesia Enviroment Statistic of Indonesia 2017. Badan Pus Stat [Internet]. 2017;91(1):186-9. Available from: http:/ / www.un-ilibrary.org/economic-andsocial-development/the-sustainabledevelopment-goals-report-2017_4d038e1e-en

3. Chaturvedi, M. K. and Bassin JK. Assessing The Water Quality Index of Water Treatment Plant, and Bore Wells, in Delhi, India. Environ Monit Assess; 2011. p. 163: 449-453.

4. Kementerian Kesehatan. Riskesdas badan Penelitian dan Pengembangan Kesehatan Departemen Kesehatan Republik Indonesia. 2016.

5. Badan Pusat Statistik. Badan Pusat Statistik Provinsi Jawa Timur [Internet]. BPS Indonesia. 2021. Available from: https:/ /jatim.bps.go.id/subject/152/lingkungan -hidup.html

6. Jesicha Mayangsari, Sudarno PA. Pengaruh 
Sistem Pengelolaan Air Limbah Domestik Terhadap Kualitas Air Sumur Ditinjau Dari Konsentrasi Tds , Cod , Klorida , Baskoro. Tek Lingkung. 2016;5(1):1-10.

7. Kementrian PUPR. Limbah Rumah Tangga dalam Lingkungan Permukiman [Internet]. 2021. Available from: http://plpbm.pu.go.id/v2/posts/LimbahRumah-Tangga-dalam-Lingkungan-Permukiman

8. Putri D. Klarifikasi Penyakit Kulit pada Manusia menggunakan Metode Binary Decision Tree Support Vector Machine (BDTSVM) Studi Kasus: Puskesmas Dinoyo Kota Malang. Malang: Universitas Brawijaya; 2018.

9. Putri ASD. Gambaran Profil Dan Faktor-Faktor Yang Mempengaruhi Kejadian Penyakit Kulit Pada Warga Yang Tinggal Di Sekitar Area Pltu, Kota Palu, Indonesia. Heal Tadulako J (Jurnal Kesehat Tadulako). 2019;5(3):29.

10. WHO. World Health Statistic 2013 [Internet]. World Health Organization. 2013. Available from:

https://www.who.int/gho/publications/world _health_statistics/EN_WHS2013_Full.pdf

11. Kemenkes. Profil Kesehatan Indonesia 2016. Jakarta: Kemenkes; 2017.

12. Desmawati, Dewi AP, Hasanah O. Hubungan Personal Hygiene Dan Sanitasi Lingkungan Dengan Kejadian Skabies Di Pondok Pesantren

Al-Kautsar Pekanbaru. Univ Riau. 2015;2(1):62837.

13. Greita M.S.Timpal, Woodford B.S. Joseph RHA. Hubungan Antara Personal Hygiene Dengan Keluhan Gangguan Kulit Di Asrama Putra Sma Kristen 2 (Binsus) Tomohon. 2020;9(7):184-9.

14. Lusiana and M. Suryani. Metode Systematic Literature Review untuk Mengidentifikasi Isu-Isu dalam Software Engineering, SATIN (Sains dan Teknol. Informasi). Vol. Vol. 3, No. 2014.

15. Sedua, N., Pinontoan, O. R. \& Sumampo O. Gambaran Sanitasi Lingkungan Pada Balita Penderita Diare Di Kelurahan Pondang Kecamatan Amurang Timur Kabupaten Minahasa Selatan Tahun 2016. Hasanuddin J Public Heal. 2016;1-10.

16. Asmadi, Khayan, dan Kasjono H. Teknologi Pengolahan Air Bersih. yogyakarta: Gosyen Publishing; 2011.

17. Kementrian Pekerjaan Umum dan Perumahan rakyat. panduan pembangunan perumahan dan pemukiman pedesaan Edisi Sumur Gali. 2016;143.

18. Rachmawati H. Pengaruh Kondisi Fisik Sumur dan Penurunan Kualitas Air (BOD) terhadap Kejadian Penyakit (Studi Kasus IndustrixSoun di
DesaxManjung Kecamatan Ngawen Kabupaten Klaten). Media Kesehat Masy Indones. 2019;18(2):19-22.

19. Amaliah AR. Analisis Kualitas Air Sumur Gali Ditinjau Dari Parameter Kimia ( $\mathrm{Cl}$ Dan Fe ) Di Kelurahan Mangempang Kecamatan Barru Kabupaten Barru Sekolah Tinggi Ilmu Kesehatan Makassar, Indonesia Alamat Korespondensi : Nama Koresponden Institusi penulis Email penulis. 2020;5(2). Available from: http://ojs.stikespanritahusada.ac.id/index.php/j $\mathrm{kph} /$ article/download/368/177

20. Jesika P, Hilal N. Hubungan Jenis Sumber Air Dan Personal Hygiene Dengan Kejadian Penyakit Dermatitis Di Desa Kedungrandu Kecamatan Patikraja Kabupaten Banyumas Tahun 2016. Bul Keslingmas. 2017;36(4):494-500.

21. Achmadi U. Dasar-Dasar Penyakit Berbasis Lingkungan. Jakarta: PT Rajagrafindo Persada; 2011. pp. 18-25.

22. Depkes RI. Perilaku Hidup Bersih dan Sehat di Rumah Tangga. Jakarta: Depkes RI; 2012.

23. Isro'in Laily dan SA. Personal Hygiene. yogyakarta: Graha Ilmu; 2012. p. 1-51.

24. Wulandari A. Hubungan Personal Hygiene Dan Sanitasi Lingkungan Dengan Kejadian Skabies Pada Santri Di Pesantren Ulumul Qur'an Kecamatan Bebesen Kabupaten Aceh Tengah. Global Health Science; 2018. p. 3(4), 322-328.

25. Akmal dkk. Hubungan Personal Hygiene dengan Kejadian Skabies Di Pondok Pendidikan Islam Darul Ulum, Palarik Air Pacah, Kecamatan Koto Tangah Padang. Kesehat Andalas. 2013;2 No 3.

26. Maharani A. Penyakit Kulit, Perawatan Pencegahan dan Pengobatan. yogyakarta: Pustaka Baru Press; 2015.

27. Sajida A, Santi DN, Naria E. Hubungan Personal Hygiene Dan Sanitasi Lingkungan Dengan Keluhan Penyakit Kulit Di Kelurahan Denai Kecamatan Medan Denai Kota Medan Tahun 2012. J Lingkung dan Kesehat Kerja. 2012;2(2):18.

28. Alfat W, Susilawaty A, Mallapiang F, Amansyah M, Basri S. Penilaian Risiko Kesehatan Lingkungan dari Personal Hygiene dan Sanitasi Terhadap Keluhan Penyakit Kulit di Pulau Badi Kabupaten Pangkep. Hig J Kesehat Lingkung [Internet]. 2020;6(1):42-51. Available from: http://garuda.ristekbrin.go.id/documents/detai $1 / 1718426$

29. Legiawati L, Yusharyahya S, Sularsito S, Setyorini N. Insidens Penyakit Kulit di Divisi Dermatologi Geriatri Poliklinik Kulit dan Kelamin Rumah Sakit DR. Cipto Mangunkusumo Tahun 2008-2013. Mdvi. 2017;44(1):20-6.

30. Anonim. Dermatitis Kontak dan Hubungannya 
Farida Sugiester S, Tri.Joko, Nurjazuli; Literature Review : Kualitas Sumur Gali Dan Personal Hygien Berhubungan Dengan Gangguan Kesehatan Kulit Di Indonesia

dengan Profesi [Internet]. Perdoski. 2017. Available from: https:// perdoski.id/article/detail/278-cari-tahutentang-dermatitis-kontak-dan-hubungannya-

dengan-profesi\#: :text=Pengertian Dermatitis

Kontak\&text=Gejalanya antara lain ditandai dengan,iritasi atau memicu reaksi alergi.

31. Ahyanti M, Purwono P. Risiko Penyakit Kulit Akibat Kerja di Perusahaan Perkebunan dan Pengolahan Karet. J Kesehat. 2019;10(1):39. 